\title{
Transformation of Residential Space as an Adaptation Process during the COVID-19 Pandemic
}

\author{
Anisa ${ }^{*}$, Finta Lissimia ${ }^{1}$, , Ratna Dewi Nur'aini ${ }^{1}$, Ashadi $^{1}$, Munirah Radin Mohd Mokhtar ${ }^{2}$ \\ ${ }^{1}$ Universitas Muhammadiyah Jakarta, Indonesia \\ ${ }^{2}$ Universiti Teknologi Mara, Perak Malaysia \\ *anisa@umj.ac.id
}

\begin{abstract}
A residence is a place to live that accommodates daily activities. Under normal conditions, housing is used as a place to unwind after work and school outside the home. Since December 2019 major changes have taken place globally that have an impact on housing. This change was due to the rapid spread of the COVID-19 virus and reached various regions. Changes due to the spread of the Covid-19 virus have caused changes in the order of life because all activities that were initially carried out outside the home, have shifted to being carried out indoors. This happens because to reduce the impact of the spread of the virus, humans must practice social distancing. The biggest change that occurred was the shift from formal school activities and work to housing. With the addition of this activity, the residence must be able to be used functionally and meet comfort for the smooth running of activities in it. The purpose of this study is to identify, describe, and interpret changes in the function of space in residential areas as an adaptation process during a pandemic. The research method used is qualitative with purposive sampling. This qualitative research was conducted inductively by observing and interviewing the research case. Data were taken purposively on 6 residential areas in Jakarta, Depok, Bogor, Tangerang, and Bekasi. The results of this study are changes that occur in residential spaces in the form of non-physical changes, namely by adding activities that are accommodated in the space. Physically the space has not changed, this shows that the non-physical changes that occur are an adaptation process carried out by residential users. The adaptation process that occurs begins with adjusting activities to the available space in the dwelling. In the process of adaptation that occurs will choose a room that has the character as the need for new activities during the pandemic. In the end, housing can provide a positive response to the COVID-19 pandemic with flexibility in the use of space to accommodate new functions.
\end{abstract}

(C) 2021 IJBESR. All rights reserved.

Keywords: Change, Occupancy, Adaptation, Covid-19 Pandemic

\section{Introduction}

Humans need space as a place to carry out daily activities. The container is manifested in a space whose name is adjusted to the activities contained in it. Some human activities are carried out inside the building and some are outside the building. Space can be defined as a container that has clear boundaries and definitions. Space boundaries are not always in the form of physical elements on all sides of the space but can also be realized with partial limiting elements.
Under normal conditions, humans will carry out many activities inside and outside the dwelling. Occupancy is a place where most people carry out activities, especially personal ones. The spaces in the dwelling are clearly defined, have certain activities and distinctive characteristics. For example, the living room is used to receive guests and similar activities that can be accessed by the public. As a place for public activities, the living room is a space that is easy to see visually and easily accessible in terms of achievement. 
Major changes occurred in residential spaces when the month of December 2019 spread and spread the COVID-19 virus. This major change is happening worldwide and has an impact on many aspects of human life. Human activity is one of the aspects affected by the spread of the COVID-19 virus. Due to the easy and fast transmission of this virus, the recommendation for social distancing is one solution. Victims fall quickly in a short time because of the ease with which this virus spreads. Based on this, all activities that cause people to crowd together are stopped. It can be seen at the beginning of the spread of this virus in Indonesia, activities outside the home that lead to human encounters were limited. Schools were closed, and learning was carried out remotely from their homes. A class that was originally defined physically, turns into a virtual class. The office as a place that is widely used for work, is also closed and replaced with work from home. Places of trade, markets, shops and related to consumption are limited by the number of users. Learning and working activities do not stop, but these activities change places. If under normal conditions, morning activities together at home are then continued with activities outside the home, in a pandemic condition, the activity of going to work becomes non-existent. Studying and working activities are 2 activities that move from outside the residence into the residence.

Meanwhile, the residence has not been used to accommodate formal activities such as studying and working. Learning that has been done at home is learning informally, to repeat and prepare lessons at school. Likewise with work activities, work that is mostly done at home is self-employed, so the character and place needed is different from formal work in the office. Based on this background, research to examine changes that occur in residential spaces is important to do. The purpose of this study is to identify, describe and express the meaning of changing residential space as an adaptation process during the COVID-19 pandemic. After conducting this research, it is hoped that there will be findings that explain the meaning behind the changes in residential space and the adaptations made by residents to sudden changes related to the COVID-19 pandemic.

\section{Material and Methods}

This research is a phenomenological qualitative research, which aims to identify, describe, and reveal the meaning of changes in residential space during the COVID-19 pandemic. Data collection in research cases was carried out by purposive sampling, namely taking research cases based on certain objectives. In research with purposive sampling, the number of cases studied cannot be determined at the outset. The number of cases will stop when the theme of the findings in the case has been found repeated in other cases. The criteria for taking research cases include: (1) There are changes in activities that affect the function of space as a result of the pandemic; (2) Case studies can be observed and interviewed for data related to space activities and functions before the pandemic; (3) The case study is a simple building with a maximum area of $54 \mathrm{~m} 2$.

The data in this study consisted of 2 kinds which were obtained by observation and interview methods. The data obtained from observation is data on changes in the spaces in the dwelling. While the data obtained from the interviews are the activities and functions of the residential space before the pandemic and during the pandemic. The data obtained from observations and interviews were then given a code (Coding) to find the themes of the findings. The themes of the findings obtained from coding the data are then categorized to make it easier to see the relationship between themes (memos). The process of analyzing the data in qualitative research was carried out twice. The first stage of the analysis process 
was carried out simultaneously with data collection in each case. The second stage of the analysis process is carried out when data collection in the case has been completed and the findings have been found in each case. This second stage of analysis is the final stage of analysis, namely conducting a dialogue between the themes of the findings to interpret the meaning behind changes in residential space during the COVID-19 pandemic.

In general, the stages in this research can be explained as follows: (1) identifying and describing the functions and activities of residential spaces before and during the COVID-19 pandemic; (2) identify and describe changes in residential space before and during the covid-19 pandemic; (3) identify and describe adaptations made by residents during the COVID-19 pandemic; interpreting to get the meaning of changing residential space as an adaptation process during the covid-19 pandemic.

\section{Results and Discussions}

\section{Architecture and the COVID-19 Pandemic}

Architecture can be defined as the art and science of designing the built environment. Architecture is used to describe the process of planning, designing, and arriving at the results obtained. As a result of planning and design activities, architecture is a solution to problems in the built environment. The built environment is the result of human thought and work that can be utilized in their lives. Architecture covers all aspects of human life, because in essence architecture provides a place for activities carried out by humans. Architecture can be a solution to problems at any scale. On a micro scale, architecture can help solve interior and space problems. On the meso scale, architecture solves the problems of buildings and areas. Meanwhile, on a macro scale, architecture solves urban problems.
Since December 2019, humans have been shaken by a global problem, namely the spread of the COVID-19 virus. The spread of this virus crosses the boundaries of regions, countries, and even continents. The spread of this virus causes many deaths and creates a sense of fear in humans. Because the spread is relatively fast and easy, then one solution is to limit human-to-human gatherings. Because it spreads in a short time and covers a wide area and causes many victims, the spread of this virus is called a pandemic. During this pandemic, the Indonesian government also issued a policy of limiting human gatherings called social distancing in order to reduce and stop the impact of the spread of the virus.

These social restrictions have an impact on all human life. All activities are carried out in their respective homes in order to reduce the intensity of meetings and the spread of the virus. Work activities are carried out in their respective homes as work from home (WFH). Learning activities are carried out in their homes as Learning From Home (BDR). One of the technological tools that is very suitable for use for this BDR facility is a gadget [1].

This condition does not only move activities from work to home, or activities from school to home. But furthermore, this condition causes humans to have to make various adaptations to these sudden changes. For example, in BDR activities, parents face challenges in assisting their children in learning. Under normal conditions children study at school together with the teacher. When learning from home, children must be assisted by parents, especially for elementary school age children. In the literature it is stated that parents must overcome the child's mood, condition a pleasant learning atmosphere, and must divide time between work and accompanying children to study [2]. The role of parents in learning activities from home is to accompany and motivate children in doing the tasks assigned by the teacher. 
Collaboration between parents and teachers must be compact and need good planning so that learning activities will be effective [3]. COVID-19 restrictions are changing the workplace, study, commerce and recreation. The architecture must be able to adapt to these changes. The accelerated adoption of online, digital, and remote technologies has forced the built environment discipline to respond immediately [4].

This sudden change caused considerable pressure on everyone. There is no other way but to adapt to these changes. During this pandemic, it is the family who plays an important role in adapting, including preventing the spread of the virus. In the literature it is stated that the family has the function of dealing with and preventing the spread of disease outbreaks and implementing a healthy lifestyle [5]. Social distancing was then followed by the slogan stay at home, with the aim that individuals and groups should only leave the house for very important purposes. So there have been several changes related to changes in human habitation. which has an important effect on the behavior and lifestyle of users. These changes are mainly related to: (1) Considering the inside-out relationship; (2) Individual daily life activities such as work, entertainment, sleeping, eating, family gatherings and communication with others through virtual emptiness and accumulation within a certain spatial framework and limited to the level of space/component/source of material; (3) Changes in behavior due to the nature of the political, social and cultural changes that have occurred and the resulting changes in housing requirements for both individuals and families [6].

In theory, the function in architecture is related to meeting the needs of human activities. A functional building is a building that can meet the needs of all human activities that are its users. (Hendraningsih in [7]). The house is also defined by Rapoport [8] as a process of living that is influenced by the activities and behavior patterns of its occupants. Changes in the design of the house will occur when residents feel uncomfortable in carrying out activities in it. Meanwhile, in the book [9] it is stated that the house is a building designed as a residence as well as a place for family development. In addition, by most people, the house also functions as a place of business such as stalls, shops, salons, and other businesses to increase family income [9]. The study of residential space is not only important to do but also will always develop according to the needs of its users

\section{Functions and Activities in Residential Space}

This section is the initial stage of the analysis, which is to identify and describe the functions and activities of the dwelling before the pandemic and during the pandemic. This study was conducted on 6 cases of houses with a building area of $<54 \mathrm{~m}^{2}$ located in Jabodetabek. In all research cases, data regarding activities before the pandemic was obtained through field observations and interviews. In qualitative research, data is taken by purposive sampling because that is why the house that is used as case 1 will lead to the next case. In case 1 , which is inhabited by 2 people, namely husband and wife, the activities before the pandemic were obtained as follows: the living room extends without a partition integrated with the dining room used to receive guests and eat, 1 room is used to rest, the warehouse as a place to store and bathroom and kitchen. In case 1 there is no business activity in the house. Activities before the pandemic in cases 2,3,4,5, and 6 have similarities with case 1 . Parents work outside the home, and children go to school. 
Table 1. Home

and research case data

\begin{tabular}{|c|c|c|c|c|c|c|c|c|c|}
\hline \multirow[t]{2}{*}{ Cases } & \multirow{2}{*}{$\begin{array}{c}\text { House } \\
\text { area }\end{array}$} & \multirow{2}{*}{$\begin{array}{l}\text { Number } \\
\text { of uses }\end{array}$} & \multicolumn{7}{|c|}{ Room name } \\
\hline & & & $\begin{array}{l}\text { Living } \\
\text { room }\end{array}$ & $\begin{array}{c}\text { Bedroom } \\
1\end{array}$ & $\begin{array}{l}\text { Bedroom } \\
2\end{array}$ & $\begin{array}{c}\text { Bedroom } \\
3\end{array}$ & $\begin{array}{c}\text { Dining } \\
\text { room/family room }\end{array}$ & $\begin{array}{c}\text { Kitchen and } \\
\text { bathroom }\end{array}$ & warehouse \\
\hline K1 & $32,5 \mathrm{~m}^{2}$ & 2 & $\sqrt{ }$ & $\sqrt{ }$ & & & $\sqrt{ }$ & $\sqrt{ }$ & $\sqrt{ }$ \\
\hline K2 & $36 \mathrm{~m}^{2}$ & 6 & $\sqrt{ }$ & $\sqrt{ }$ & $\sqrt{ }$ & & & $\sqrt{ }$ & \\
\hline K3 & $45 \mathrm{~m}^{2}$ & 6 & $\sqrt{ }$ & $\sqrt{ }$ & $\sqrt{ }$ & $\sqrt{ }$ & $\sqrt{ }$ & $\sqrt{ }$ & \\
\hline K4 & $49,2 \mathrm{~m}^{2}$ & 2 & $\sqrt{ }$ & $\sqrt{ }$ & $\sqrt{ }$ & & $\sqrt{ }$ & $\sqrt{ }$ & \\
\hline K5 & $\begin{array}{l}51,75 \\
\mathrm{~m}^{2}\end{array}$ & 4 & $\sqrt{ }$ & $\sqrt{ }$ & $\sqrt{ }$ & & $\sqrt{ }$ & $\sqrt{ }$ & \\
\hline K6 & $40 \mathrm{~m}^{2}$ & 6 & $\sqrt{ }$ & $\sqrt{ }$ & $\sqrt{ }$ & & & $\sqrt{ }$ & \\
\hline
\end{tabular}

Based on the identification and description of space functions and activities before the pandemic, it was found that from 6 research cases there were 4-7 rooms, with the same activities. The number of rooms in the research case is between 1-3 rooms, which is adjusted to the number of users. The rooms found in each research case are living room, bedroom, kitchen, and bathroom. The second stage of analysis is to identify and describe activities and functions during the pandemic. During the COVID-19 pandemic, activities in residential areas underwent changes. The amount of space in the house has not changed. Activities carried out before the pandemic also did not change. Changes can be seen in the increase in activity in the spaces in the house.

Additional activities in the research cases found include: online lectures, online BDR, online teaching, Work From Home, and selfisolation. In general, these additional activities occur due to 3 things. First, teaching and learning activities under normal conditions are carried out at schools but in pandemic conditions are carried out at home. Online lectures and online teaching activities are also included in this category. Second, under normal conditions, work activities are carried out outside the home, but during a pandemic, work activities are carried out indoors. Third, in a pandemic condition when a family member is affected by COVID-19, a room for self-isolation is needed.

The space used for school from home is the living room and terrace. The room used for online lectures and online teaching is a room. The space used for work from home is the room. Findings from spaces that have changed during the pandemic are living rooms and rooms. From the shape of the building, all cases studied did not change. The only changes that occur are the addition of functions to the space. The arrangement of furniture has not changed because home users choose to use existing furniture and use portable furniture for activities. In case study 5 , the children were not yet in school and their parents worked outside the home, so that neither BDR nor WFH were found. The new activity found is isoman activity in one of the rooms which was originally part of the living room. 
Table 2. Activities and Spaces used during the pandemic

\begin{tabular}{|c|c|c|c|}
\hline Cases & $\begin{array}{c}\text { Number of } \\
\text { uses }\end{array}$ & New activities during the pandemic & Used space \\
\hline K1 & 2 & Study online & Bedroom \\
\hline K2 & 6 & School From Home dan study online & Living room \\
\hline K3 & 5 & $\begin{array}{c}\text { School From Home, Work From Home } \\
\text { dan teach online }\end{array}$ & Bedroom \\
\hline K4 & 2 & Teach online & Living room (divided into a room) \\
\hline K5 & 4 & self isolation & Terrace and living room \\
\hline K6 & 6 & School From Home & \\
\hline
\end{tabular}

\section{Changes and Adaptations to Residential Space}

Based on the analysis in the previous section, it was found that the changes that occurred in the residential space were the addition of activities and functions to the existing space. Changes did not occur in the shape of the room or the addition of furniture. It can be stated that there has been user adaptation to space. Adaptation is an adjustment to the changes that occur. The COVID-19 pandemic is a major change that occurs suddenly and changes the order of daily life.

Change can happen slowly and suddenly. Nonphysical changes can cause physical changes, as discussed in this study. Non-physical changes that affect physical changes can be in the form of social, economic, and cultural changes that occur in society. Thus, the meaning of change is a process of gradual change from a form to a new form that is influenced by physical and non-physical factors, namely in the form of cultural, social, economic, and political changes taking into account aspects of space and time [10]. Change is also defined as the addition, subtraction, and displacement of a primary element in the built environment (Habraken, in [11]). Based on this understanding, changes can occur in several ways, including addition, subtraction, and displacement. The context in this study that occurs is a change due to the addition of activities that result in additional functions in the residential space.
Meanwhile, according to Alexander [12], several things that can be observed in the process of environmental change are: (1) Changes occur little by little or continuously; (2) Changes are unpredictable and know when they start and when they end, depending on the underlying forces; (3) The change process does not take place in stages but is comprehensive and continuous; (4) Change is closely related to the value system of the supporting population.

As stated by Megahed [13], the COVID-19 pandemic is a big change happening. However, behind this big change, there is a positive impact which is the solution to the change. Changes in the residential space studied occurred suddenly, unpredictable and unknown start and end times. The COVID-19 pandemic began to spread since December 2019 in China. At that time, the conditions in the housing that became the research case had not changed. This was observed when in December 2019 researchers were still able to see activity in the dwelling taking place normally. Suddenly, in March 2020, social distancing regulations came into effect, which suddenly shifted activities outside the home to activities inside the house. The house which was not originally designed for formal school and work, suddenly had to be able to accommodate these two activities. This makes home users to adapt for the sake of these activities without having to add space in the house. 
Learning activities that are usually carried out at home before the pandemic period is studying to prepare material at school or repeat lessons. This non-formal learning activity is carried out in a room or other room. Because the character of the activity is non-formal, there is no need for a special room. Studying can be done in the room, on the terrace, or in another room that feels comfortable. Meanwhile, during the pandemic, learning and schooling are carried out at home. Schools are conducted online, with the delivery of material like at school, but meetings between teachers and students are virtual in a virtual space. The character of the activities is different from the usual learning, because studying at school which is replaced by studying at home still has a formal character. Children are in uniform and orderly with a schedule. Another difference is that formal schooling at home for elementary school-age children still requires assistance from parents. So we need a space that allows parents to be active while monitoring the mother. Because school from home has a formal activity character, space is also needed to support this activity. So the findings from the room used by the majority are the living room because the living room is usually used for activities that are different from other rooms.

Another new activity that appears during the pandemic is working from home (WFH), in a simple house or a house with a medium size usually no special place is provided for work. This happens because usually work is done outside the home, so that in the design of the house there is no need for work activities. In the six house case studies studied, the space which is then used for work is a room because work requires a quiet atmosphere and there is no circulation across the space. In essence, the space used for work must be conducive to calm and support concentration. This is a challenge in itself for medium-sized dwellings because in addition to no space specifically used for work, they also have to share space with school from home activities which are also held inside the house.

Facing the changes that occur, home users carry out a process of adaptation to the existing space, by making several adjustments. At the beginning of the residential design, it did not include the need to study and work from home, with this pandemic there was a change that required space to be added to its function to accommodate these activities. The interpretation of the research conducted is that the occupants have the criteria to choose the space to be added to the function. These criteria, among others, relate to the nature of space, the character of the space and the size of the space. For school from home activities, the space that is chosen depends on the needs that accompany the activity. For example, for the kindergarten level, which still requires full assistance from parents, the space chosen is the same as the room used by parents to work from home. Work from home activities require a quiet and private space and look polite to carry out online activities. School from home activities for elementary school age require a different space because they require parental assistance, but not like kindergarten age. The room of choice is a common room (such as a living room) which can be monitored by parents. In contrast to students who study online, they will choose a private place such as a room.

Meanwhile, according to Habraken's theory, changes can be observed based on the order of form, territorial order, and cultural order. The changes observed are based on changes in the cultural order, focusing more on things that are implicit. These implicit things such as changes in mindset, perspective, changes in people's behavior, to the emergence of agreements among the community [11]. Based on Habraken's explanation, it can be interpreted that changes that occur in the function of the residential space studied occur suddenly, 
without predictions and cannot be predicted with certainty when it will end. So that it can be seen that there is a change in the territorial and cultural order. While the order of form does not change. Territorial order occurs because of the addition of activities and functions to existing spaces. For example, the activity in the living room initially was receiving guests, but since the pandemic the visiting activities have been minimized (some case studies did not accept guests) and the room has increased its function into a study/school room. Territorially private activities eventually extended to the living room. Public activities then shift towards the outside (terrace and courtyard). The cultural order has changed from a home for daily activities to a home for all daily activities. School and work are finally done at home. Although in a small scope and limited virtual space, working and schooling from home is a new culture that has arisen due to the pandemic. Learning is designed in such a way that it can replace schools as usual. The order of form does not occur because physically the dwelling has not changed. Only 1 case study experienced physical changes but not permanently, namely by insulating the living room into an isolation room for families affected by COVID-19. As an illustration, it can be seen in the image below where there is a room that has added activities and functions.

When presented in tabular form, it can be seen that there are generally 2 spaces that increase in function, namely the living room and the bedroom. While the terrace as a space between the inside and outside has also experienced additional functions.
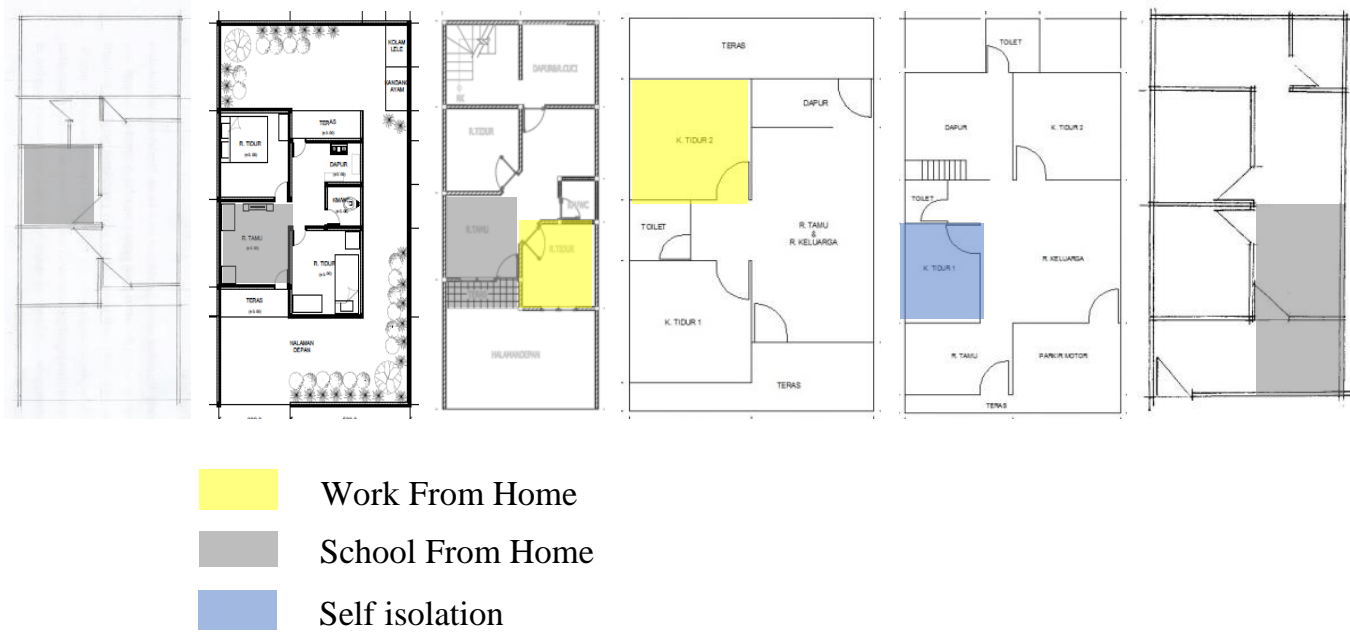

Figure 1. Spaces that have added activities and functions 
Table 3. Activities and Residential Spaces during the Pandemic

\begin{tabular}{|c|c|c|c|c|c|}
\hline Cases & $\begin{array}{l}\text { house size } \\
\text { category }\end{array}$ & $\begin{array}{l}\text { House } \\
\text { area }\end{array}$ & $\begin{array}{l}\text { New activities during the } \\
\text { pandemic }\end{array}$ & $\begin{array}{l}\text { Space that has } \\
\text { increased function }\end{array}$ & $\begin{array}{l}\text { Space that has } \\
\text { changed function }\end{array}$ \\
\hline K1 & Small & $32,5 \mathrm{~m}^{2}$ & Study online & Bedroom & - \\
\hline $\mathrm{K} 2$ & Small & $36 \mathrm{~m}^{2}$ & $\begin{array}{l}\text { School From Home dan study } \\
\text { online }\end{array}$ & Living Room & - \\
\hline K3 & Medium & $45 \mathrm{~m}^{2}$ & $\begin{array}{l}\text { School From Home, Work } \\
\text { From Home dan teach online }\end{array}$ & $\begin{array}{l}\text { Bedroom, Living } \\
\text { Room and Terrace }\end{array}$ & - \\
\hline K4 & Medium & $49,2 \mathrm{~m}^{2}$ & Teach online & Bedroom & - \\
\hline K5 & Medium & $51,75 \mathrm{~m}^{2}$ & self isolation & - & $\begin{array}{c}\text { The living room } \\
\text { where part of the } \\
\text { space becomes a } \\
\text { room }\end{array}$ \\
\hline K6 & Small & $40 \mathrm{~m}^{2}$ & School From Home & $\begin{array}{l}\text { Living Room and } \\
\text { Terrace }\end{array}$ & \\
\hline
\end{tabular}

This analysis is in line with research that is being carried out, namely that there are major changes due to the COVID-19 pandemic that have created new habits and new orders in daily life. In essence, the existence of a major event can cause architectural changes. However, these changes do not always come to physical form, but changes can occur in activity and function in physical form as was done in this study. This section is a continuation of the analysis of changes in residential space. Adaptation is a process of adapting in an effort to cope with environmental pressures. Adaptation is carried out by all living creatures, not only humans. Adaptations in animals are made to survive and keep from extinction. In the description of the analysis, it can be identified that there are non-physical changes that affect the physical space of the dwelling. This change is an adaptation process carried out by residential users, with the aim that activities are accommodated in space but do not need to make physical changes.

Table 4. Spaces that experience changes in activities and adaptations that occur

\begin{tabular}{|c|c|c|c|c|}
\hline Cases & Room & Early activity & $\begin{array}{c}\text { Additional activities during } \\
\text { the pandemic }\end{array}$ & Adaptations that occur \\
\hline K1 & Kamar & $\begin{array}{c}\text { Rest and personal } \\
\text { activities }\end{array}$ & Study online & Adding activities to the room \\
\hline K2 & Ruang tamu & Receive guests & $\begin{array}{c}\text { School from home and Study } \\
\text { Online }\end{array}$ & Activity Changes in the room \\
\hline K3 & Kamar, & $\begin{array}{c}\text { Rest and personal } \\
\text { activities }\end{array}$ & $\begin{array}{c}\text { Work From Home and teach } \\
\text { online }\end{array}$ & Adding activities to the room \\
\hline K4 & ruang tamu, teras & Receive guests & School from home & Activity Changes in the room \\
\hline K5 & Kamar & Teach Online & Adding activities to the room \\
\hline K6 & $\begin{array}{c}\text { Ruang tamu dan } \\
\text { Teras }\end{array}$ & Receive guests & Self isolation & Adding activities to the room \\
\hline
\end{tabular}

\section{The Meaning of Functional Change as an Adaptation Process}

This section is the final part of the analysis, namely the interpretation of the theme of findings regarding changes in residential space during a pandemic. Based on the previous analysis, several themes have been found, namely (1) new activities during a pandemic; (2) Space as a place of activity during a pandemic; (3) changes and adaptations that occur in residential spaces. Interpretation is preceded by a description of the memos or dialogues between the themes of the findings mentioned above. The memos obtained were 
new activities during the pandemic that were not predicted at the beginning of the house design, so that the existing space was not ready to accommodate these activities. The process that followed was a change in the form of additional activities in the space as an adaptation process by taking into account the suitability of the character of the space and the new activities that were accommodated in that space.

The interpretation of the memos is that there are several activities as a form of adaptation carried out by users in residential spaces, namely:

1) Merging several activities in one space. As described in the previous section, there is the addition of new activities during the pandemic, but users adapt to existing residential spaces. So what happens is the merging of several activities in one space. The merging of some of these activities is not done randomly but is adjusted to the characteristics of the activities and user convenience. It is undeniable that comfort plays an important role in choosing the space used for activities.

2) Share private space. In general, in housing there is a division of space into public, private, and service. Public spaces will be represented by spaces that are easy to see visually and easily accessible in terms of achievement. This public space allows people from outside to participate in using it. Private space in the house has a larger part with more complex activities than public space. Architecturally, this private space is not easy to reach and see by other than users. In a pandemic condition, private space has characteristics that are suitable for new activities that are private and require tranquility. For example, work from home activities, or learning activities for high school and college levels. This can be interpreted that the private space is also experiencing adaptation during the pandemic. Private spaces with the characteristics of complex activities are actually able to answer the space needs during a pandemic.

3) Shifting activities towards the outside of the dwelling. In the context of social distancing as a solution to the COVID-19 pandemic, meeting activities are minimized. So that public space becomes a space that is not optimally used, due to meeting restrictions. If under certain conditions there is a visiting activity, then the visiting activity will be carried out in the yard, on the terrace, or separated by a territorial barrier (fence). This can be interpreted as an adaptation in the form of a shift in activities towards the outside. During the pandemic, it is more comfortable to receive guests on the terrace or in the yard because it is easier to implement health protocols. By receiving guests on the terrace or in the yard, distance can be maintained and air circulation is smooth, thereby reducing the risk of being exposed to the virus. In a further interpretation, the comfort of activities outside the dwelling can ultimately be an adaptation solution. Residential users can do several activities outside the home.

4) Expansion of the private area of the residence. The Covid-19 pandemic condition causes all activities to be carried out indoors so that the spaces in the house become private spaces. Under normal conditions the division of space in the house into public, private and service. In its development during the pandemic, public space shifted outside the home and private space expanded. The expansion of the private area is caused by three things, firstly because of the increase in private activities in the house. Second, because there has been a shift in public space towards the outside of the house. Third, because of the convenience of choice in space adaptation. 


\section{Conclusion}

Based on the analysis and meaning that has been carried out in research that aims to identify, describe and express the meaning of changes in residential space as an adaptation process during the covid-19 pandemic, it can be concluded:

1) There has been a change in residential space due to the COVID-19 pandemic. These changes occur non-physically, namely in the form of increasing activities that are accommodated in space.

2) The process of change in the form of adding activities to the space while still paying attention to the suitability of the characteristics of the space and the new activities that are accommodated in that space. In addition, user comfort is a factor that influences the consideration of space selection. The adaptation process carried out is in the form of non-physical adaptation because physically the space does not change.

3) The forms of adaptation that can be found include 4 things, namely: (1) combining several activities in one space; (2) Sharing private space for new activities; (3) Shifting activities outward from the dwelling; (4) Expansion of the private area of the dwelling.

\section{Acknowledgement}

This research is a grant from Ministry of Higher Education entitled "Program Kompetisi Kampus Merdeka” (PKKM) 2021.

\section{References}

[1] Pebriana, Putri Hana. 2017. Analisis Penggunaan Gadget terhadap Kemampuan Interaksi Sosial pada Anak Usia Dini. Jurnal Obsesi: Jurnal Pendidikan Anak Usia Dini, Volume 1 No. 1.

[2] Astuti, Isti Yuli dan Harun. 2021. Tantangan Guru dan Orang Tua dalam Kegiatan Belajar dari Rumah Anak Usia Dini pada Masa Pandemi Covid-19. Jurnal Obsesi: Jurnal Pendidikan Anak Usia Dini, Volume 5 No. 2 (1441-1463)
[3] Ayuni, D., Marini, T., Fauziddin, M, \& Fahrul, Y. 2021. Kesiapan Guru TK Menghadapi Pembelajaran Daring Masa Pandemi Covid-19. Jurnal Obsesi: Jurnal Obsesi: Jurnal Pendidikan Anak Usia Dini, Volume 5 No. 1 (414-421)

[4] Maturana, Beatriz and Ashraf M. Salama. 2021. Architecture, urbanism and health in a post-pandemic virtual world. International Journal of Architectural Research Vol 15 No 1

[5] Yuliati. 2021. Peran Keluarga dalam Pencegahan Wabah Covid-19. Jurnal Pengabdian Masyarakat Volume 7 No.2

[6] Bettaieb, Donia M and Reem Alsabban. 2020. Emerging living styles post-COVID-19: housing flexibility as a fundamental requirement for apartments in Jeddah. International Journal of Architectural Research vol 15 No 1

[7] Simbolon, Agustina Sri Rezeki. 2020. Perubahan Fungsi Ruang Hunian Sederhana dengan Pendekatan Arsitektur Perilaku. Tesis Fakultas Teknik Universitas Sumatera Utara, Medan.

[8] Rapoport, Amos. 1969. House, Form and Culture. Prentice Hall, Inc. London.

[9] Budihardjo, Eko. 1994. Percikan Masalah Arsitektur, Perumahan Perkotaan. Yogyakarta: Gadjah Mada University Press.

[10] Susanti, I., Dewi, NIK., Permana, AY. 2018. Teritorial dalam Proses Perubahan Hunian. Jurnal Arsitektur Zonasi Volume 1 Nomor 1.

[11] Sesotyaningtyas. 2015. Perubahan Hunian Dengan Perspektif Spasial Dan Tatanan Budaya: Komparasi Permukiman Kumuh Bang Bua, Thailand Dan Kampung Naga, Indonesia. Geoplanning Journal of Geocities and Planning Vol 2 No 2.

[12] Alexander, Christopher. 1987. A New Theory of Urban Design, Oxford University Press.

[13] Megahed, 2020. Indoor Air Quality: Rethinking rules of Building design Strategies in post pandemic Architecture.

https://pubmed.ncbi.nlm.nih.gov/33197423/ 
(This page is intentionally left blank) 